\title{
TAXPAYERS'PERCEPTION OF TAX EVASION STUDIED FROM TAX KNOWLEDGE, TAX FAIRNESS, AND TAX DICRIMINATION
}

\author{
BimaAdityaNugaha ${ }^{1}$ \\ AndrianantenainaHajanirina ${ }^{2}$ \\ President UniversityBekasi \\ bimaaditya95@gmail.com \\ hajanirina@president.ac.id
}

\section{A R T I C L E I N F O}

\section{Article history:}

Received : 3 May 2020

Revised : 13 May 2020

Accepted : 20 May 2020

JEL Classification:

Key words:

tax knowledge, tax fairness, tax discrimination, taxpayers' perception of tax evasion

DOI:

https://doi.org/10.33508/rima.v3i1.2747

\begin{abstract}
A B S T R A C T
This paper attempts to study taxpayers' perception on tax evasion while tax knowledge, tax fairness, and tax discrimination are considered. It sampled individual taxpayers who are registered in the tax office of Sekayu Regency, Palembang. Purposive sampling is used and sample of 200 respondents are obtained. Data collection is done by questionnaire method distributed to respondents. The results of this study indicate that tax knowledge, tax fairness, and tax discrimination are significantly associated with perception of tax evasion.
\end{abstract}

\section{INTRODUCTION}

National development is development that takes place continuously aiming to improve people's welfare. It is carried out to improve all aspects of people's lives, and the development of the overall system of state administration. To be able to realize this goal, the State must explore sources of funds from various sources both domestically and abroad. One of the biggest state revenues is revenue from the tax sector.

Table 1Targets and Realization of Tax Revenue

\begin{tabular}{|c|c|c|c|}
\hline Years & Tax Revenue Target & Realization of TaxRevenue & Percentage (\%) \\
\hline 2013 & 1148,4 & 1077,3 & $93,8 \%$ \\
\hline 2014 & 1246,1 & 1146,9 & $92 \%$ \\
\hline 2015 & 1489,3 & 1240,4 & $83,3 \%$ \\
\hline 2016 & 1503,3 & 1249,5 & $83,1 \%$ \\
\hline 2017 & 1472,7 & 1125,1 & $76,4 \%$ \\
\hline
\end{tabular}

Source: www.kemenkeu.go.id(Ministryof Finance) Accessed September 26, 2018

From the table above we can find out between tax returns and their realization. It can be seen from the table above that the realization of tax revenue from 2013 to 2017 is decreasing. From the data above, from 2015 to 2017 the most dropped dramatically because the percentage of tax revenue was less than $90 \%$, even in 2017 is only $76.4 \%$. Two thousand eighteen is the fourth year where Indonesia's executive cabinet development program aimed to achieve the sustainable development goals to create prosperity and social fairness to all citizens was implemented. The government responded in 2018 through the determination of the theme of fiscal policy, namely "Strengthening Fiscal Management to Accelerate Equitable Growth". www.kemenkeu.go.id (Ministry of Finance). Three fiscal strategies that are adopted in 2018 are: 
- Optimizing state revenues as well as maintaining the climate for investment;

- Increasing the efficiency of sending budget and increasing productive spending to support main and vital programs;

- Advocating the financing of an efficient, innovative, and sustainable

In Indonesian budget of 2018, state revenues are projected at $\mathrm{Rp} 1,894.7$ trillion. This number derives from tax revenues in the amount of $\mathrm{Rp} 1,618.1$ trillion, from non-tax state revenues amounting to Rp.275.4 trillion and bequest of Rp1.2 trillion. Source: https://www.kemenkeu.go.id/apbn2018 Accessed in (September 26 ${ }^{\text {th }}$ 2018)

On the state revenue from tax sectors, is one of the dominating components in building the Foundation of the structure of domestic revenue in Indonesia. National development is basically carried out by the community and by the Government. Therefore, taxes are the dues that are derived from the public, and then the public awareness of the role and in terms of the obligation to pay taxes should always be improved. The importance of taxes for the continuity of development no doubt and tax revenue contributed to state revenue.

Tax evasion will have an effect, according to McGee (1994) tax funds which should be accepted by the state to build public facilities, finance government activities do not reach the state, so they will hamper development, the right of the poor to obtain subsidies from the state cannot be realized. Many elements are hampered because funds from tax payments do not enter state finances.

Previous research revealed that the qure were several factors that effect on tax evasion, Kiri (2016) stated that the main factors that usually affect the level of tax evasion in a country can be categorized into:

- Traditional factor (which includes tax rate, penalty rate and audit probability),

- Institutional factors (which includes corruption, cost compliance and confidence),

- Socio-cultural factors (which includes age, sex, education, social rules etc),

- Macroeconomic factors (which includes GDP, unemployment rate and inflation) and

- Businesses characteristics (which includes size, ownership and industry).

It is vital to have the research on how the factors like audit probability, tax rate and penalty rate affect tax evasion in a country to adjust its fiscal politics. Although there are many factors believed to influence tax evasion, this research classifies all of these factors into three main factors that are believed to be the reason for the percepetion of tax evasionin Sekayu,Palembang.

Table 1 Targets and Realization of Tax Revenue in Sekayu

\begin{tabular}{|c|c|c|c|}
\hline Years & Tax Revenue Target & Realization of TaxRevenue & Percentage (\%) \\
\hline 2013 & $1,049,109$ & 964,755 & $92 \%$ \\
\hline 2014 & 995,840 & 890,794 & $89 \%$ \\
\hline 2015 & $1,481,457$ & 950,611 & $64 \%$ \\
\hline 2016 & $1,266,926$ & $1,025,363$ & $81 \%$ \\
\hline 2017 & $1,327,575$ & $1,043,313$ & $79 \%$ \\
\hline
\end{tabular}

Source: KPP PratamaKabupatenSekayu

Tax evasion often occurs in Indonesia on individual level. The most difficult case in the news is GayusTambunan (IIIA Civil
Class, Directorate General of Tax under the Ministry of Finance). Gayus was involved in three layers of articles, namely 
corruption, money laundering and tax evasion. This case has a negative impact on some taxpayers in tax compliance (Rini, 2013). Tax fraud cases have recently occurred in corporate level, one of the cases of alleged bribery of tax elimination by PT EK Prima Export Indonesia is Rp. 6 million (Rozie, 2017).

In a study conducted by McGee (2006), tax evasion was considered an ethical actbecause of the lack of fairness in the use of money derived from taxes, the high level of government corruption, and the benefits of tax money less felt by the public. Whereas according McGee et al. (2008) based on literature and religious thought, it was revealed that tax evasion is always unethical because of the pressure of thought that should not underestimate fellow human beings. Thus, when someone does tax evasionit will make other people look bad and this is a form of humiliation for humanity.

\section{LITERATURES AND HIPOTHESES}

Tax Fairness is a legal goal achieved through the Law and fair tax collection. A tax implementation is said to be fair in legislation if it is applied and in accordance with the ability of each Taxpayer. While fair in its implementation is to grant the taxpayer the right to file an objection, delay in tax payment and appeal to the tax court in accordance with Law Number (No).17 of 1997.

One of the difficult problems encountered in tax collection is how to realize tax fairness because fairness has a broad perspective where fairness between each individual is different. The presumption of the importance of tax fairness for an inside taxpayer tax payments will affect the attitude of taxpayers in their tax activities. The higher the level of tax fairness, the behavior of tax evasion is seen as unethical behavior. On the contrary, the lower the level of tax fairness, the behavior of tax evasion is considered to be ethically inclined behavior. From the explanation above, it can be concluded that the first hypothesis in this study is:

H1: Tax fairness affects the taxpayers' perception of tax evasion.

The level of taxpayer's understanding of tax regulations becomes important in determining the attitudes and behavior of taxpayers in carrying out obligations in paying taxes (Mutia, 2014). Knowledge of community tax regulations through both formal and non-formal education will have a positive impact on the awareness of taxpayers to pay taxes. (Hardiningsih\&Yulianawati, 2011).

According to Sholichah (2005), taxpayers who do not comprehend the regulations regarding tax clearly tend to be disobedient taxpayers. The taxpayers will assume tax evasion is unethical if they have a good understanding of taxation.

From the explanation above, it can be summed up that the second hypothesis in this thesis is:

H2: Tax knowledge has an effect on taxpayers' perception of tax evasion.

The Theory of Planned Behavior explains that when going to do something, Taxpayers will have beliefs about normative expectations from others and motivation to fulfill those expectations (normative belief). The emergence of thoughts about discrimination in taxation for taxpayers will affect the attitudes and intentions of individuals in paying taxes.

According to Suminarsasi and Supriyadi (2011) the higher the level of discrimination in taxation, the behavior of tax evasion is seen as ethically inclined behavior, whereas the lower the level of discrimination in taxation, the behavior of tax evasion is seen as unethical behavior.

Nickerson et al. (2009) found that discrimination is one of the factors that influence tax evasion. This is supported by research conducted by Suminarsasi and Supriyadi (2011), Ningsih (2015) and Silaen (2015) who found that discrimination had a positive effect on 
taxpayers' perceptions of the ethics of tax evasion. Based on this explanation, the third hypothesis is:

H3: Tax discrimination has an effect on the taxpayers' perception of tax evasion.
Thus, we use regression analysis to test the hypotheses with the following model:

$$
P T E_{i}=a_{1}+\beta_{1} T K_{i}+\beta_{2} T F_{i}+\beta_{3} T D_{i}+\varepsilon_{i}
$$

Where:

PTE : Taxpayers' perception of
tax evasion
$\begin{array}{ll}\text { TK } & \text { : Tax Knowledge } \\ \text { TF } & : \text { Tax Fairness } \\ \text { TD } & : \text { Tax Discrimination } \\ \text { a } & : \text { Constant number } \quad(Y \\ \text { value, if } X=0) \\ \text { e } \quad: \text { Tolerated error }(5 \%):\end{array}$

\section{Result Interpretation}

Sample

The populations in this study are all individuals belonging to taxpayers who are still active in paying their tax obligations and registered in tax office in Sekayu Regency. The method of determining the sample in this study used a purposive sampling technique that is the determination of samples with certain considerations. Some of the sample criteria in this study are. The samples taken in this study will use a purposive sampling method or technique. The reason for using purposive sampling or judgment sampling is the reason that researchers will choose samples that meet the research criteria so that they can provide answers that support this research.
The criteria for the research sample are taxpayers who have a taxpayer identification number and are registered in tax office in Sekayu Regency, so that they can identify and determine the answers that correspond to the questions in the questionnaire related to the research variables.

The reason for the sample selection, because the realization of tax revenue in Sekayu Regency is almost not realized according to the target every year. Besides the majority are young between 20-25 years old with $53 \%$ of the respondents. Young generation can easily change in mind and have higher degree of trial on all possible action including tax evasion.

In this research, we use questionnaire survey after a pilot study is done. We test for the validity and reliability of the questionnaire indicators. All are found valid and reliable with value of CronbachAlpah more that 0.75 .

Based on the results of multiple regressions testing regarding the effect of tax knowledge, tax fairness, and tax discrimination on taxpayers' perception of tax evasion, it can be interpreted as follows:

Table 3. Result

\begin{tabular}{|l|r|r|r|}
\hline \multicolumn{1}{|c|}{ Variables } & Coefficient & \multicolumn{1}{c|}{ t } & p-value \\
\hline (Constant) & -.794 & -3.026 & .003 \\
\hline Tax Knowledge & .535 & 9.589 & .000 \\
\hline Tax Fairness & .214 & 4.594 & .000 \\
\hline Tax Discrimination & .337 & 7.218 & .000 \\
\hline
\end{tabular}


The Influence of Tax Knowledge on Taxpayers' Perception of Tax Evasion

In the first hypothesis states that tax knowledge affects taxpayers' perception of tax evasion, andthe researcher proves that the results of the study there is positive effect between data knowledge on taxpayers' perception of tax evasion. This shows that the higher the taxpayer's understanding of taxes, the higher the taxpayer's perception of tax evasion. This is because the taxpayer's who have access to higher education tend to know more about tax regulations and as a result, they would know about how to avoid taxes and tax evasion.

The results of this research are consistent with the research conducted by Lewis (1982) people who have a higher education would be more knowledgeable about tax rules and fiscal policy as well as find out about the ways tax avoidance and tax evasion so that it cannot be said that the more highly educated are obedient than the low educated. The results of the research argue that knowledge of tax has a significant and positive impact on taxpayers' perception on tax evasion.

\section{The Influence of Tax Fairness on}

Taxpayers' Perception of Tax Evasion.

In the second hypothesis states that tax fairness affects taxpayers' perception of tax evasion, andthe researcher proves that the results of the study there is a partial positive effect between fairness towards tax evasion seen based on a significant value of less than 0.05 . This proves that the higher of the tax fairness, it will make the higher on the taxpayers' perception of tax evasion.

The results of the research are consistent with the research conducted by McGee (2008), Nickerson et al. (2009), Suminarsasi (2011). The results of the research argue that tax fairness has a positive and significant impact on taxpayers' perception on tax evasion. The consideration of whether tax evasion is an ethical or unethical matter often depends on perceptions of each taxpayer. Based on the data obtained, the level of tax justice in Sekayu is already high. Taxes are deemed fair by taxpayers if the tax charged is proportional to the ability to pay and benefits to be received, so that taxpayers feel the benefits of the tax burden that has been incurred. Although tax fairness is classified as high, it has no effect in reducing the level of perceptions of taxpayers on tax evasion. This indicates that high tax justice cannot reduce the occurrence of tax evasion. This is likely because justice is only in the tax law but not in its application.

The Influence of Tax Discrimination on

\section{Taxpayers' Perception of Tax Evasion}

In the third hypothesis states that tax discrimination affects taxpayers' perception of tax evasion, and the researcher proves that the results of the study there is a partial positive influence between tax discrimination against taxpayers' perception of tax evasion is seen based on a significant value of less than 0.05 . This proves that the higher the tax discrimination increases the taxpayers' perception of tax evasion.

The results of the research are consistent with the research conducted by McGee (2008), Nickerson et al. (2009), Suminarsasi (2011) that shows that discrimination has a significant positive correlation to tax evasion. Researchers argue that the fiscal policy of foreign affairs related to the ownership of the taxpayer identification number is a form of discrimination. Foreign fiscal exemption should be granted to all taxpayers either have a taxpayer identification number or do not have a taxpayer identification number. This is an equal rights to citizens who have been equally fulfilling their obligations. In addition, the policy allowed zakat taxation liability relief as a factor and the presence of free zone tax benefits only some community groups only. So, it will result in jealousy on groups that do not benefit from these policies, which would later lead to acts of tax evasion. 


\section{Conclusion}

Considering the perception of tax evasion, it is found that tax knowledge and tax discrimination have role on the perception of tax evasion. On the other hand, increase in knowledge of tax regulations triggers the perception on how if evasion will be a solution to certain life condition. Besides, while tax discrimination increases, the perception on evading the tax increases as well. It is on contrary of the fairness, it might be because the fairness that are felt by the respondent do not match the ideal fairness that is defined, thus fairness increases in line with the perception to evade tax. It might be a solution to the local government to increase socialization on tax payment willingness and awareness. The research was only conducted in one of the tax offices in Sekayu regency, Palembang, so the results of the study could not be obtained both interpret the perceptions of all taxpayers in Sekayu district regarding tax evasion. Further research needs to add broader variables, such as tax sanctions, tax services and others. Because there are still many factors that influence taxpayers' perception of tax evasion.

\section{REFERENCES}

Abrahams, N. B., \& Kristanto, A. B. (2016). Persepsi Calon Wajib Pajak dan Wajib Pajak terhadap Etika Atas Penggelapan Pajak di Salatiga. Berkala Akuntansi dan Keuangan Indonesia, 1(1).

Adi Nugroho, R. Z. (2012). Faktor-Faktor Yang Mempengaruhi Kemauan Untuk Membayar Pajak Dengan Kesadaran Membayar Pajak Sebagai Variabel Intervening (Studi Kasus Pajak Orang Pribadi Yang Melakukan Pekerjaan Bebas Yang Terdaftar di KPP Pratama Semarang Satu). Diponegoro Journal of Accounting, 1(2), 1-11.

Ajzen. (1991). The Theory of Planned Behavior. Organizational Behavior and Human Decision Process, 50, 179-211.

Ajzen, I. (2002). Constructing a TPB Questionnaire: Conceptual and Methodological Considerations. 50(2), 179-211.

Akintoye IR, T. G. (2013). The effect of tax compliance in economic growth and development in Nigeria. British J. Art Social Sci., 11(2).

Anwar, S. (2014). Metodologi Penelitian Bisnis. Jakarta: Salemba Empat.

Ariwodola, J. (1998). personal Income Taxation in Nigeria including Capital Gains Tax. JAA Nigeria.

Ayua, I. (1999). The Nigerian Tax Law, Ibadan Spectrum Law .

Ayua, I. (1999). The Nigerian Tax Law, Ibadan Spectrum Law .

Beekum, R. (2004). Etika Bisnis Islam. Yogyakarta: Pustaka Pelajar.

Bernadette, e. (2010). Tax Compliance of Small Business Owners. Int . J. Entrepr. Beh. Res., 18(3), 330-351.

Elfffers. (1991). Tax Evasion: An Experimental Approach. Cambridge University Press.

Farayola, G. (1987). Guide to Nigerian Taxes. Lagos: All Crowns Nig. Ltd.

Gibson, J. I., \& Donnelly, J. (1991). Organizations: Behavior, Structure, Processes (7 ed.). Homewood, Homewood: Irwin.

Gunadi. (2007). Akuntansi Pajak. Gramedia.

Hardiningsih, P., \& Yulianawati , N. (2011). Faktor - Faktor yang Mempengaruhi Kemauan Membayar Pajak (The Factors That Influence The Willingness To Pay The Tax). Dinamika Keuangan dan Perbankan, 3(1), 126-142.

Hasibuan, R. S. (2014). Faktor-Faktor Yang Mempengaruhi Persepsi Wajib Pajak Mengenai Etika Atas Penggelapan Pajak (Tax Evasion) (Studi Empiris di KPP Pratama Medan-Polonia).

Irmansyah, A. (2016). MK Tolak Gugatan UU Pengampunan Pajak. Retrieved December 18, 2018, from kbr.id: 
http://m.kbr.id/berita/122016/m k_tolak_gugatan_uu_pengampuna n_pajak/87481.html

Kariyoto. (2010). Effect of Tax Reform, Tax Audit, Awareness and Compliance Taxpayers Against Taxation Performance. (5), 1-13.

Laksono JP, A. (2007). Analysis of Factors Affecting Taxpayer Compliance in Manufacturing Industrial Company in Semarang. Journal of Economics, 4(8), 35-63.

Machogu CG, \& Amayi JB. (2013). The Effect of Taxpayer Education on Voluntary Tax Compliance, Among SMES in Mwanza City Tanzania. Int. J. Market. Financ. Serv. Manage. Res., 2(8), 12-23.

Maryani, T., \& U, L. (2001). Survei Atas Faktor-Faktor Yang Mempengaruhi Sikap dan Perilaku Etis Akuntan (Vol. II).

Marziana, B. (2010). The Relationship between Perception and Level of compliance Under self Assesment system - A Study In The East Coast Region. J. Glob. Bus. Econ., 241-257.

McGee, \& R. W. (2006). Three Views on The Ethics of Tax Evasion. Journal of Business Ethics, 67(1), 15-35.

Mc\& Ranjana Gupta. (2008). The Ethics of Tax Evasion: An Empirical Study of New Zealand Opinion. Working Paper Florida International University Chapman Graduate School of Business.

Mcgee, Robert, W., Aljaaidi, K. S., \& Musaibah, A. S. (2012). The Ethics of Tax Evasion: A Survey of Administrative Sciences Students in Yemen. International Journal of Business and Management, 7(16), 110.

McGee,, R. W., \& Lingle, C. (2008). The Ethics of Tax Evasion: A Survey of Guatemalan Opinion. (Mcgee, Ed.) Taxation And Public Finance in Transtition And Developing Economics, 481-495.

McGee,, R.W., Benk, S., Yildirim, H., \& Kayikci, M. (2011). The Ethics of
Tax Evasion: A Study of Turkish Tax Practitioner Opinion. European Journal of Social Sciences, 18, 3.

Ministry of Finance. (2018). Retrieved September 26, 2018, from https://www.kemenkeu.go.id/ap bn2018

Mortenson, E. R. (2006). Tax Evasion.

Murni, \& Linda Puspa Sari. (2013). Pengaruh Keadilan, Kualitas Pelayanan Pajak, dan Kemungkinan Terdeteksinya Kecurangan Terhadap Persepsi Wajib Pajak Mengenai Tax Evasion. Jurnal Akuntansi Universitas Trunojoyo Madura, 2(1), 1-15.

Mutia, S. T. (2014). Pengaruh Sanksi Perpajakan, Kesadaran Perpajakan Pelayanan Fiskus, dan Tingkat Pemahaman terhadap Kepatuhan Wajib Pajak Orang Pribadi (Studi Empiris pada Wajib Pajak Orang Pribadi yang terdaftar di KPP Pratama Padang.

Nama dari Indonesia Muncul di Panama Papers. (2016). Retrieved September 28, 2018, from Pontianakpost:

http://www.pontianakpost.co.id/ 2961-nama-dari-indonesiamuncul-di-panama-papers

Nickerson, I. P. (2009). Presenting the Dimensionality of An Ethics Scale pertaining To Tax Evasion. Journal of Legal, Ethical and Regulatory Issues, 12(1), 1-12.

Ningsih, D. C. (2015). Determinan Persepsi Mengenai Etika Atas Penggelapan Pajak(Tax Evasion) (Studi Pada Mahasiswa Jurusan Akuntansi Fakultas Ekonomi dan Bisnis Universitas Brawijaya). Jurnal Akuntansi.

Nwachukwu. (2006, September 1). Institutions indulge in Tax Evasion Despite Huge Profits they make in Nigeria.

Pareek, U. (2001). Perilaku Organisasi. Jakarta: Uni Press. 
Pareek, U. (2004). Understanding Organisational Behaviour. New Delhi: Oxford University Press.

Plano, \& Jack C. (2001). Kamus Analisa Politik. Jakarta: Rajawali Pers.

Rachmadi, W. (2014). Faktor-Faktor Yang Mempengaruhi Persepsi Wajib Pajak Orang Pribadi Atas Perilaku Penggelapan Pajak. 1-40.

Rahayu, S. K. (2010). Perpajakan Indonesia: Konsep dan Aspek Formal. Yogyakarta: Graha Ilmu.

Gee, B. (2007). The Ethics of Tax Evasion, New Zealand and USA Opinion. (5), 1-15.

McGee, R. W. (1994). Is Tax Evasion Unethical, Kansas Law Review (Vol. 42). USA.

McGee, R.,

Rahman, I. S. (2013). Pengaruh Keadilan, Sistem Perpajakan, Diskriminasi, dan Kemungkinan Terjadinya Kecurangan Terhadap Persepsi Wajib Pajak mengenai Etika Penggelapan Pajak. Journal of Economics, 2(5), 1-25.

Rini. (2013). Kasus Gayus Tambunan Pengaruhi Kepercayaan Wajib Pajak. Retrieved September 30, 2018, from Republika: http://www.republika.co.id/berit a/ekonomi/makro/13/10/01/mtz en4-kasusgayus-tambunanpengaruhi-kepercayaan-wajibpajak

Rozie. (2017). Terdakwa Kasus Suap Pajak Akui Teman Lama Adik Ipar Jokowi. Retrieved October 10, 2018, from Liputan $6:$ http://news.liputan6.com/read/2 863538/terdakwa-kasussuappajakakui-teman-lama-adikipar-jokowi

Sholichah, I. (2005). ). Perilaku Wajib Pajak Terhadap Tingkat Keberhasilan Penerimaan Pajak Bumi dan Bangunan di Kabupaten Gresik. Jurnal Loos, 3(1), 62-75.

Siahaan, M. P. (2010). Hukum Pajak Material. Yogyakarta: Graha Ilmu.
Silaen, C. (2015). Pengaruh Sistem Perpajakan, Diskriminasi, Teknologi dan Informasi Perpajakan terhadap Persepsi Wajib Pajak Mengenai Etika atas penggelapan pajak (Tax Evasion). Journal Faculty of Economics, 2(2), 114.

Soyode, L., \& Kajola , S. (2006). Taxation: Principles and Practice in Nigeria (1 ed.). Ibadan: Silicon.

Suluhbali. (2016). Artikel Panama Papers Pintu Masuk Penyelesaian Korupsi Indonesia. Retrieved October 2, 2018, from Suluhbali: http:/ / suluhbali.co/artikelpanama-papers-pintu-masukpenyelesaian-korupsi-indonesia/

Suminarsasi, W. (2012). Pengaruh Keadilan, Sistem Perpajakan dan Diskriminasi Terhadap Persepsi Wajib Pajak Mengenai Etika Penggelapan Pajak.

Tribune. (2016). Ferry KAse Jangan Ada Diskrimiasi Dalam Pemungutan Pajak. Retrieved December 18, 2018, from Tribunenews: http:/ / m.tribunnews.com/dprri/2016/10/13/ ferry-kase-janganadadiskrimiasi-dalampemungutan-pajak

U, S., \& R, B. (2013). Research Methods for Business. United KIngdom: Wiley \& Sons Ltd.

Weldegiorgis, D. K. (2010). Assessment of Taxpayers voluntary compliance with Taxation: A case of Mekelle City, Tigray, Ethiopia, Thesis. Mekelle:MU. 1-87.

Wicaksono, M. A. (2014). Pengaruh Persepsi Sistem Perpajakan, Keadilan Pajak, Diskriminasi Pajak dan Pemahaman Perpajakan terhadap Perilaku Penggelapan Pajak (Studi Empiris Pada Wajib Pajak Orang Pribadi Terdaftar di KPP Pratama Purworejo). 1-57.

Zain, M. (2008). Manajemen Perpajakan. Jakarta: Salemba Empat.

\section{APPENDIX}


$\underline{\text { Validity test }}$

\begin{tabular}{|c|c|c|c|c|}
\hline Variable & Item & Value of coefficient validity & Value r Table & Explanation \\
\hline \multirow{15}{*}{$\begin{array}{l}\text { Taxpayer's } \\
\text { perception } \\
\text { of tax } \\
\text { evasion }\end{array}$} & Tpe1 & 0.879 & 0.361 & Valid \\
\hline & Tpe2 & 0.834 & 0.361 & Valid \\
\hline & Tpe3 & 0.847 & 0.361 & Valid \\
\hline & Tpe4 & 0.912 & 0.361 & Valid \\
\hline & Tpe5 & 0.759 & 0.361 & Valid \\
\hline & Tpe6 & 0.900 & 0.361 & Valid \\
\hline & Tpe7 & 0.854 & 0.361 & Valid \\
\hline & Tpe8 & 0.908 & 0.361 & Valid \\
\hline & Tpe9 & 0.895 & 0.361 & Valid \\
\hline & Tpe10 & 0.726 & 0.361 & Valid \\
\hline & Tpe11 & 0.843 & 0.361 & Valid \\
\hline & Tpe12 & 0.792 & 0.361 & Valid \\
\hline & Tpe13 & 0.797 & 0.361 & Valid \\
\hline & Tpe14 & 0.864 & 0.361 & Valid \\
\hline & Tpe15 & 0.851 & 0.361 & Valid \\
\hline \multirow{6}{*}{$\begin{array}{c}\text { Tax } \\
\text { Knowledge }\end{array}$} & TK1 & 0.803 & 0.361 & Valid \\
\hline & TK2 & 0.775 & 0.361 & Valid \\
\hline & TK3 & 0.890 & 0.361 & Valid \\
\hline & TK4 & 0.886 & 0.361 & Valid \\
\hline & TK5 & 0.798 & 0.361 & Valid \\
\hline & TK6 & 0.885 & 0.361 & Valid \\
\hline \multirow{4}{*}{$\begin{array}{c}\text { Tax } \\
\text { Fairness }\end{array}$} & TF1 & 0.513 & 0.361 & Valid \\
\hline & TF2 & 0.459 & 0.361 & Valid \\
\hline & TF3 & 0.788 & 0.361 & Valid \\
\hline & TF4 & 0.764 & 0.361 & Valid \\
\hline \multirow{5}{*}{$\begin{array}{c}\text { Tax } \\
\text { Discrimination }\end{array}$} & TD1 & 0.815 & 0.361 & Valid \\
\hline & TD2 & 0.607 & 0.361 & Valid \\
\hline & TD3 & 0.914 & 0.361 & Valid \\
\hline & TD4 & 0.783 & 0.361 & Valid \\
\hline & TD5 & 0.793 & 0.361 & Valid \\
\hline
\end{tabular}

Reliability test

\begin{tabular}{|c|c|c|}
\hline Variable & Value of Cronbach alpha & Decision \\
\hline Taxpayer's perception of tax evasion & 0.974 & Reliable \\
\hline Tax Knowledge & 0.944 & Reliable \\
\hline Tax Fairness & 0.798 & Reliable \\
\hline Tax Discrimination & 0.908 & Reliable \\
\hline
\end{tabular}

